\title{
Theology amongst the sciences: A personal view from the University of Oxford
}

\author{
Author: \\ Susan E. Gillingham ${ }^{1,2}$ \\ Affiliations: \\ ${ }^{1}$ Faculty of Theology, \\ University of Oxford, \\ England, UK \\ ${ }^{2}$ Research Fellow, \\ Department of Old \\ Testament Studies, University \\ of Pretoria, South Africa \\ Correspondence to: \\ Susan Gillingham \\ Email: \\ susan.gillingham@worc. \\ ox.ac.uk

\section{Postal address:} \\ Worcester College, Walton \\ Street, Oxford, Oxfordshire \\ OX1 2HB, UK \\ Dates: \\ Received: 22 July 2011 \\ Accepted: 27 Sept. 2011 \\ Published: 07 Dec. 2011 \\ How to cite this article: \\ Gillingham, S.E., 2011, \\ 'Theology amongst the \\ sciences: A personal view \\ from the University of \\ Oxford', Verbum et Ecclesia \\ 32(1), Art. \#576, 8 pages. \\ http://dx.doi.org/10.4102/ \\ ve.v32i1.576
}

C 2011. The Authors. Licensee: AOSIS OpenJournals. This work is licensed under the Creative Commons Attribution License.
The paper focuses on two individuals who have each made a seminal contribution to the debates between theology and the sciences in Oxford - Charles Darwin (in the mid-19th century), and Richard Dawkins (from the 1990s to the present day). It introduces Darwin by way of a more personal and visual view from Worcester College Chapel. The restoration of the chapel took place at about the same time as the debates between Huxley and Wilberforce in the Oxford University Museum over Charles Darwin's On the Origin of the Species. The first part of the paper then traces these debates back: first to an earlier period of disputation represented by Galileo Galilei (c. 1564-1642), and then to a period of greater accommodation represented by Isaac Newton (1643-1727). Darwin represents a third, more controversial, stage. The paper then looks at a fourth period, from the mid-20th century onwards, which is marked by more eirenical attempts to demarcate science and theology by seeing the former again as asking the 'how' questions and the latter, the 'why' questions. It then focuses on a fifth, more disputatious stage, which was initiated by Richard Dawkins, professor in the Public Understanding of Science until 2008. Professor Dawkins challenges the idea that theology cannot be studied, because its focus is a non-existent object, 'God'.

The second part of the paper looks at various Oxford projects and Oxford theologians who have risen to this contemporary challenge. They include the work of the Ian Ramsey Centre; Justin Barret's and John Trigg's joint $£ 2$ million project, supported by the John Templeton foundation, which examines scientific ideas about religion and the mind; Richard Harries, Bishop of Oxford from 1987 to 2006, who has conducted a number of media interviews with Richard Dawkins; Keith Ward, who has written several books engaging not only with Dawkins but is also the Cambridge Professor of Mathematics, Stephen Hawking; and Alistair McGrath, who has a doctorate in both science and theology, and who has similarly written and entered into public debates challenging Dawkin's ideas.

The paper ends by referring to John Barton, Professor of the Interpretation of Holy Scripture at Oxford, who argues that provided that theology is a subject which is properly critical, open to alien truth and combines both intellectual and emotional modes of perception, it can set an example for almost any academic discipline, both in the humanities and the sciences. The conclusion is therefore that, far from theology having to become more like another science, the sciences might be challenged to become more like theology.

\section{Introduction}

Although Darwin was himself a Cambridge man, it was at Oxford that the famous debate, convened by the British Association for the Advancement of Science, took place in 1860 on whether, in the light of Darwin's On the Origin of Species by means of natural selection (1859), it was still possible to read the creation stories in Genesis literally and to regard God as Creator of the Universe. Over a century later it was an Oxford biologist, Richard Dawkins, whose book The Selfish Gene (1989) initiated an equally lively debate about whether theology is a subject at all as its focus is a non-existent entity, namely God. These two figures - Darwin and Dawkins have at any rate influenced my Oxford perspective on theology and the sciences and my paper emphasises their pivotal contributions to these debates.

\section{Charles Darwin, the Nineteenth Century Debates and Worcester College}

I am forcefully reminded of Charles Darwin whenever I enter the chapel of my Oxford College, Worcester, which was completely redecorated in 1864. Its key theme is 'God and Nature'. Although little of the connection is documented, its artwork and architecture were undoubtedly influenced by discussions in Oxford from the 1860s onwards about the relationship between Religion and Science which were initiated by Thomas Huxley, a colleague of Darwin, and Samuel Wilberforce, then Bishop of Oxford, who argued heatedly about the implications of Darwin's theory. This 
was at the same time as the designs for the restoration of Worcester College Chapel were being considered by the Fellows of the College: the art-architect was William Burges (1827-1881). Many of these designs were a visual response, with a good deal of light-hearted scientific skepticism, to the issues, which had a resonance in Victorian society beyond the confines of Oxford. Burges covered the entire chapel walls, windows, ceiling, floor and the wooden carvings on the pews - with images of the entire created order in praise of God. He used the words of a canticle used at Matins, the Benedicite, which calls several times upon all creation to 'praise the Lord', and depicted these various calls in vivid imagery (see Figure 1).

The calls upon the birds of the air to 'praise the Lord' includes two frescoes of birds, at the centre of which are two nonflying birds, the dodo and kiwi; the dodo is again found in the carving on the pew ends, and as an extinct species, adds a touch of humour (see Figure 2).

The fresco drawings on the walls which call upon the 'fishes of the sea' to 'praise the Lord' are of fish found primarily around the Galapogos Islands; again another touch of humour might have been intended here, as a Worcester alumnus was one of those who accompanied Darwin on the Voyage of the Beagle in 1831 (Gillingham 2009:26).

The entire chapel is brimming with the whole of the created order - green 'things', animals, birds, fishes, mountains and the seas - in praise of God; but there is one intriguing absence - not a single monkey, despite the fact that monkeys, in humorous poses, were one of Burges' key motifs in other architectural assignments, for example covering the walls and ceilings of Castel Coch and Cardiff Castle in Wales. So a notable symbol of Darwin's theory of evolution has been discreetly omitted from Worcester Chapel ${ }^{1}$. But in every other way, whether in the smaller designs of tiny birds flying near the ceiling of the chapel, and the flaura and fauna produced in minute detail on the walls, or in the larger frescos on each side of the seven windows (see Figure 3), there is a clear affirmation that the design and order in the natural world reflect the design and order of a Creator.

Bishop Samuel Wilberforce was invited to give the first sermon when the chapel was re-opened in 1865. His text, which was on the importance of hearing the Voice of God, using the boy Samuel at Shiloh as an illustration, alluded to these issues more than once:

For this purpose these walls exhibit to you outlines of all God's creation praising and magnifying their Lord (...). You know that there is something more than the powers you share with the beasts of the field (...). That there is something more than this mere material world; yea, that there is more than even mere intellectual capacity, and a voice speaking to that intellect.

(Wilberforce 1865:7-9, quoted in Gillingham 2009:27)

\section{Charles Darwin and other stages of discourse between theology and the sciences}

These far-off Oxford debates, set back in the middle of the 19th century, are nevertheless an important part in a sequence of different disputations between the natural sciences and theology, which took place from the sixteenth century onwards. It is possible to classify this sequence into five stages, two of which preceded the publication of On the Origin of Species by means of natural selection (1859) and two others, which followed it.

1.I am thinking here of the famous exchange between Huxley and Wilberforce when the latter apparently asked whether Huxley's descent from a monkey was from his grandmother or grandfather, to which Huxley seems to have replied that he would have no shame in claiming his ancestors as monkeys, but he would have dreadfu shame to think he was connected with someone who would not face scientific truth.

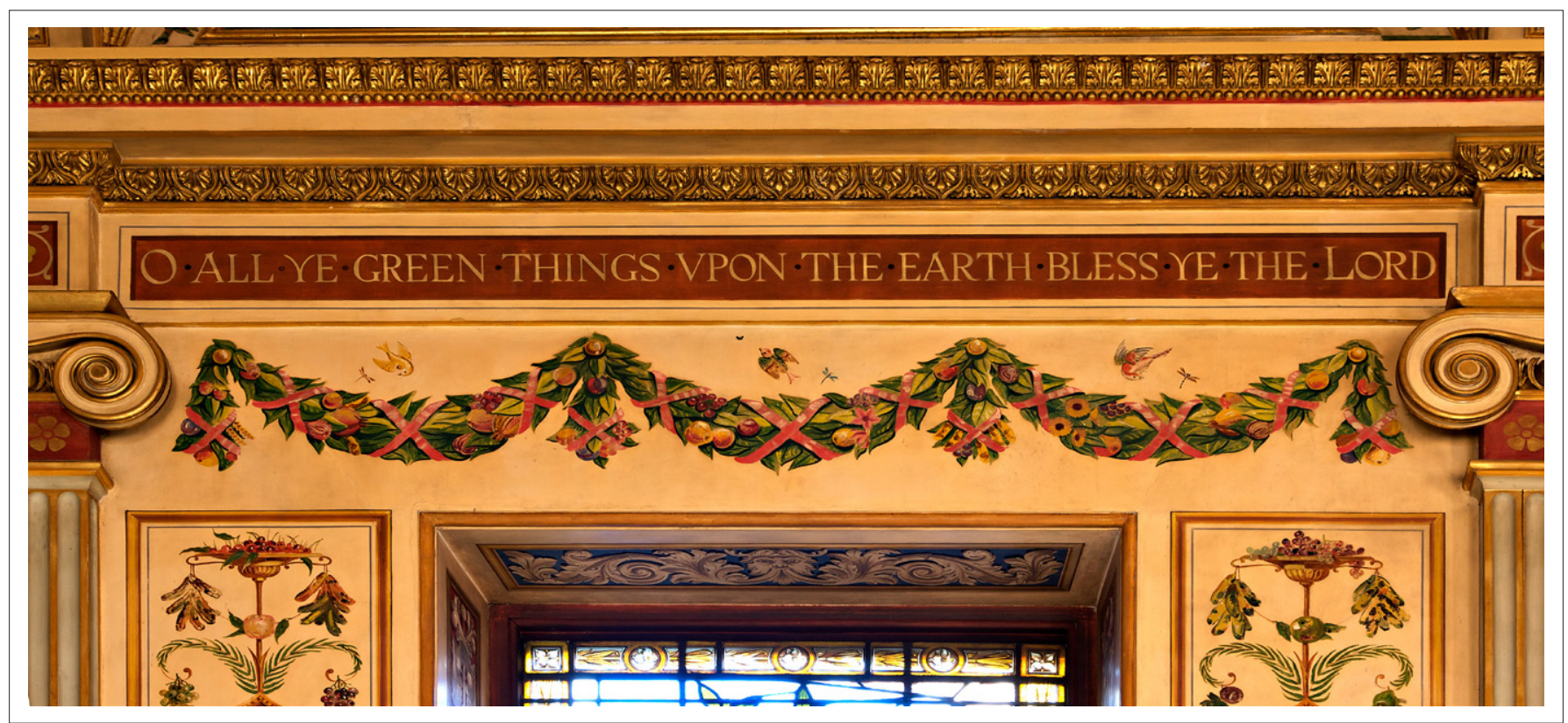

Source: Gillingham, S.E., 2009, Encountering Burges: Reflections on the Art and Architecture of the chapel at Worcester College, Oxford, Third Millennium Publishing, London, UK FIGURE 1: Part of the 'Benedicite' frieze in Worcester Chapel, Oxford. 


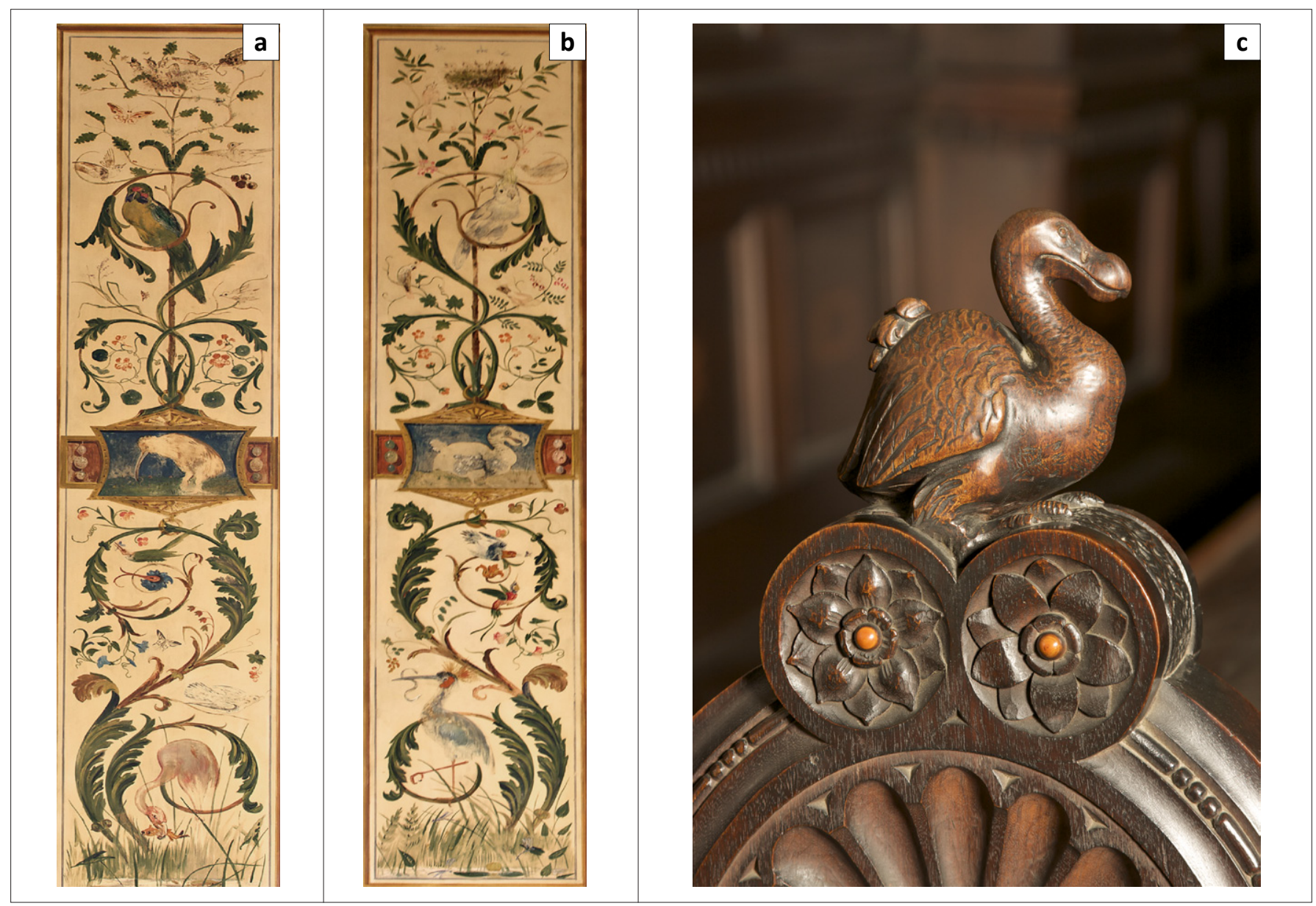

Source: Gillingham, S.E., 2009, Encountering Burges: Reflections on the Art and Architecture of the chapel at Worcester College, Oxford, Third Millennium Publishing, London, UK

FIGURE 2: The nonflying birds that are included in the call to the birds of the sky to 'praise the Lord' are the (a) kiwi and the (b) now exitinct dodo. The dodo is again found at the bench ends (c).

The first stage was one of dispute and tension, best represented by Galileo Galilei (c.1564-1642), whose training as an astronomer led him to speak against the church's teaching that the sun, rather than the earth, was the centre of the universe. These controversies initiated a bitter period of conflict between what might now be called 'scientific materialism' and 'biblical literalism'2. The second stage is best described as one of accommodation rather than conflict, represented for example by Isaac Newton (1643-1727), who as well as being gifted in physics, mathematics and astronomy was more of a reflective (albeit unorthodox) theologian than Galileo. Newton adapted the famous analogy of God as the Great Designer of a clockwork cosmos, which he had wound up and then left it to its own laws of motion. The problem with Newton's re-evaluation of the church's teaching was that this distant Deity had little in common with the Christian teaching on an immanent and incarnate God. The third stage is, as we have seen, best represented by Charles Darwin (1809-1882), whose theory of evolution initially caused the rift between religion and science to grow deeper still ${ }^{3}$. Creation itself could now be explained without reference to

2.Galileo, who 'rode full tilt into the windmill of the Inquisition' was reinstated 1992 by the Catholic Church and is often called the 'Father of Physics', or indeed of modern science (Heilbron 2010:362-363)

3.Unlike Galileo, his contribution to science was honoured in his lifetime and he was buried in state at Westminster Abbey, close to Isaac Newton.
God: hence Burges's visual response in Worcester Chapel, using humour and non-verbal rhetoric to place God the Creator back in relationship with his created order.

A fourth stage straddles the end of the 19th to near the end of the 20th century. During this period theologians - several from Oxford, as we shall see shortly - increasingly claimed that the 'why' questions - about the meaning of life and morality - belonged more to the sphere of Religion, leaving the 'how' questions to the expertise of Science. One example was the theological response to the 'Big Bang' theory (developed by Georges LeMaître in the 1920s and popularised by Frederick Hoyle in a radio broadcast in 1949) which theologians began to claim could still be seen within the context of the very beginning of the creation of the universe billions of years ago $\mathrm{ag}^{4}$. Another example was the response to the theory of Quantum Physics, whose origins can be traced to the beginning of the 20th century. During the course of its development the interest of theologians had been roused, because they noted that its theories of uncertainty at the infinitesimal subatomic level brought into question Newton's mechanical laws of motion and so suggested the presence of God 'within the

4.An interesting example of this is in Ellen van Wolde's Stories of the beginning: Genesis 1-11 and other creation stories, (1996:251ff), who argues that the Big Bang Theory is a twentieth century 'mythical' account of creation, as also is the Theory of Evolution (pp. 259ff). 


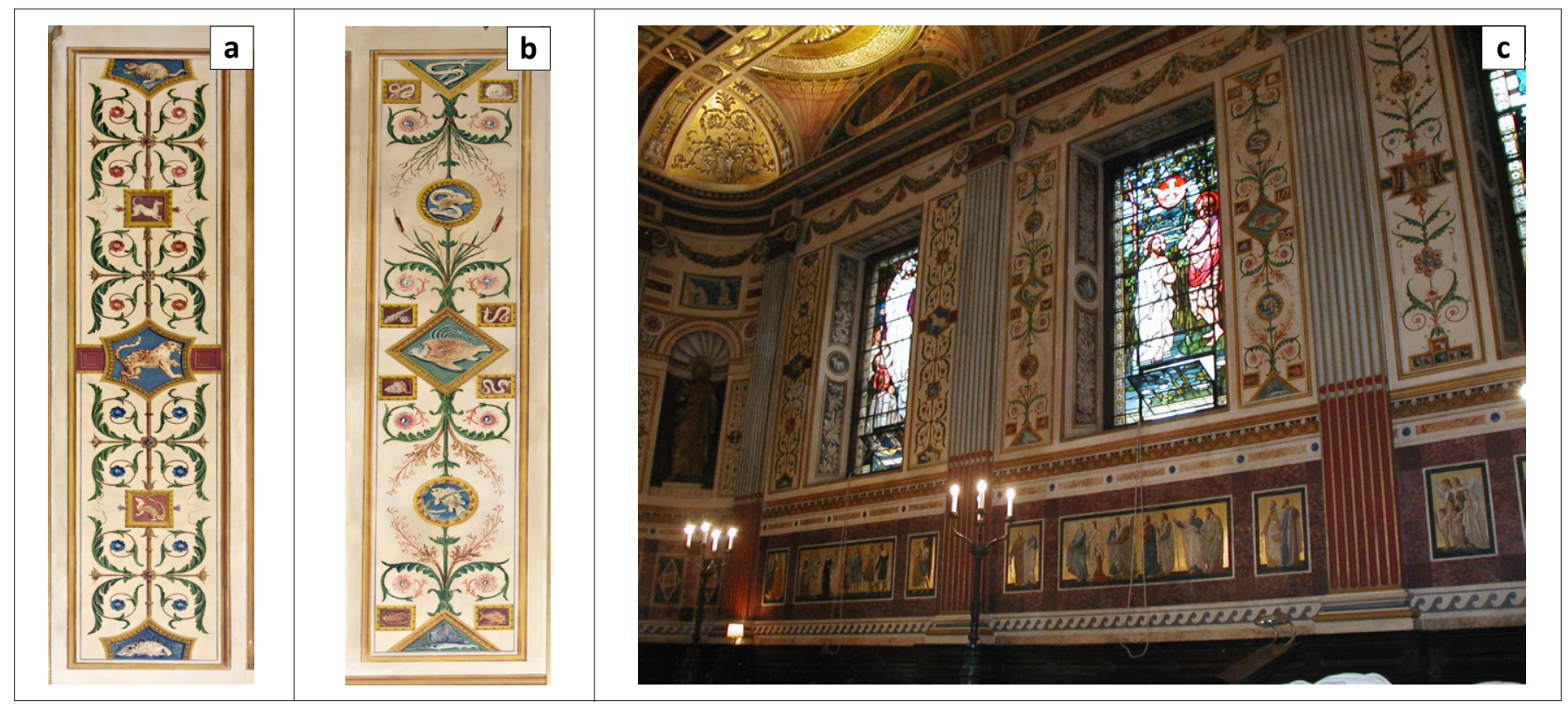

Source: Gillingham, S.E., 2009, Encountering Burges: Reflections on the art and architecture of the chapel at Worcester College, Oxford, Third Millennium Publishing, London, UK

FIGURE 3: The minute details can be seen in the wall panels where (a) the beasts of the field and (b) the fish of the sea praise God. These panels are set between two of the windows inside the chapel at Worcester College, Oxford (c).

gaps $^{\prime 5}$. Alternative arguments for some continuing evolution within the created order allowed process theologians to advocate, again, the immanence of God (see Cobb \& Griffin 1976). Other responses are to be found in various medical advances, especially in the field of neuroscience, where some theologians advocate a more holistic relationship between the mind and body, arguing that a dualistic understanding of the physical and the spiritual is a false dichotomy, and thus proposing that God is present in all aspects of life ${ }^{6}$.

\section{Richard Dawkins and the fifth stage of discourse between theology and the sciences}

The fifth stage in the development of this discourse brings our observations back to Oxford. In the early 1990s a particularly strident voice was heard in the work of Richard Dawkins, who was, until 2008 Charles Simonyi Professor of the Public Understanding of Science at Oxford University. His target was not only the more closed literalist minds of faithful fundamentalists who argued for the superior truth of religion over science but also those theologians who had argued for a more subtle relationship between religion and science (Dawkins 1994). One of the best-remembered slogans propounded by Dawkins in 1993-1994 was 'theology is not a subject'. In part this had been a reaction to Susan Howatch, the successful author of the Starbridge Series and the St. Benet's Trilogy, who in 1992 had made a generous benefaction to Cambridge University to create the Starbridge Lectureship in Theology and Natural Science. In part it had been influenced by responses in the media in 1993 to the comments by David Jenkins, at that time Bishop of Durham, who questioned whether the stories of the birth and death of Jesus Christ should be understood in a literal and historical sense.

\footnotetext{
5.An account and criticism of theologians who have proposed 'God-of-the-gaps' theories is in Dixon's Science and religion: A very short introduction (2008:45ff).

6.Much of this analysis of these stages in the growth of science has been helped by a pithy article by Vallely (2008:13)
}

Dawkins used what he saw as the misguided benevolence of Howatch and the well-publicised scepticism of Jenkins to argue that the study of theology cannot exist, because it is the study of a non-existent object, 'God' (Dawkins 2006:147-150).

However, some 15 years later, it could be argued that Dawkins' work, at least in Oxford, has achieved quite the opposite of what might have been expected - a better and more constructive discourse between theology and the sciences. Several collaborative projects have been influenced in part by reactions to his work, encouraging a healthy debate about the limitations as well as the potential of each discipline of science and theology.

\section{Five responses from Oxford theologians}

One good example of constructive discourse is the Ian Ramsey Centre for Science and Religion, founded in 1985 (actually before much of the controversy initiated by Dawkins, but very much a resource for the later response to it) for the study of religious beliefs in relation to the sciences and medicine. It is part of the theology faculty in the University of Oxford and offers regular seminars and conferences which are open to all University tutors as well as to graduate students and interested members of the public, bringing together scientists, philosophers and theologians. The website of the centre shows the breadth of interests explored in the seminars, many of which have been provoked by critics such as Dawkins (Ian Ramsey Centre n.d.). The series in the winter term of 2009, for example, focussed on the legacy of Darwin's Origin of species by means of natural selection (1859), some 150 years after publication also looking at Dawkins' work and at 'Christian Darwinism'. Other recent seminar topics include evolution and ethics, creationism and intelligent design, natural theology and God, chance and purpose; the seminars also provide a forum for assessing major publications, such as 
John Brooke's Science and religion: Some historical perspectives, first published in 1991, which was re-assessed under the title 'Science and Religion: New Historical Perspectives'7. A threeday conference in July 2010, jointly sponsored by the Ian Ramsey Centre in Oxford and the International Society for Science and Religion was on the theme of 'God and Physics', which was also a celebration of the 80th birthday of John Polkinghorne, and was held in Oxford in the Department of Physics $^{8}$.

A second example is a most interesting collaborative project between theology and the sciences (University of Oxford 2008). In 2008 a grant of almost $£ 2$ million was made by the John Templeton foundation to the Ian Ramsey Centre and the Centre for Anthropology and Mind, also in Oxford, for the development of the study of the cognitive science of religion, examining scientific ideas about the meaning of religion and its origin in the human mind. This includes all aspects of mind and intelligence, working at present in fields as diverse as evolutionary biology, neuroscience, anthropology, philosophy, physics, linguistics and computer science - in order to make better sense of the full range of human behaviour and the role of religion and religious belief within it. Dr Justin Barrett, a senior researcher at the Centre for Anthropology and Mind, editor of The Journal of Cognition and Culture, and author of Why Would Anyone Believe in God? (2004) is one of the two collaborators. This quotation explains his role in the project:

The cognitive science of religion allows us to take a subtler approach to questions such as the alleged divisiveness of religion - looking at whether the conflicts associated with religion are a product of human nature itself.... The exciting questions in this field are in the details - how does the mind vary in its response to different forms of religion, such as polytheism and monotheism for example, and what is the relationship between religion and evolutionary biology - is religion a part of the selection process that has helped us survive or merely a by-product of evolution?

(University of Oxford 2008)

Professor Roger Trigg, a senior researcher at the Ian Ramsey Centre and emeritus professor of Philosophy at the University of Warwick is the other co-collaborator. He is the joint editor of the Ashgate series of monographs on Science and Religion and his most recent book is Religion in public life: Must faith be privatised? (2007). He explains his role in the project as follows:

Religion has played an important role in public life over the last few years and the debate about the origin of religion, and how it fits into the human mind has intensified. This study will not prove or disprove any aspect of religion, but it will allow us to have a more intelligent and informed debate and to support this with

7.Professor Brooke, Professor of the History of Science at Lancaster University, and once President of the British Society of the History of Science and of the historical section of the British Association for the Advancement of Science, was a previous director of the centre. See Brooke (1991).

8.John Polkinghorne was a Professor of Mathematical Physics at the University of Cambridge from 1968-1979, when he then began to train as an Anglican Priest is a widely respected writer on the relationship between science and religion. His Exploring reality: The intertwining of science and religion,
2005, is one of his most recent and best known works. a vastly expanded and improved supply of evidence particularly the quantitative skills which tried to be less common amongst theologians.

(University of Oxford 2008)

In many ways, this has little to do with any particular response to Professor Dawkins, although ironically it engages with many of the issues with which, until 2008, a holder of the Chair in the Public Understanding of Science would also be engaging. At the very least it offers a practical and positive response to Dawkins' charge that God could be spoken of in the same way as Father Christmas or the Tooth Fairy (Ukraine.com 2001) ${ }^{9}$. When the 2008 Templeton project is complete, it will at least raise questions about whether or not religion is merely a matter of heredity or simply a selfinduced response to the 'Selfish Gene' (Dawkins 1976).

As well as the ongoing work of the Ian Ramsey Centre and the Centre for Anthropology and Mind, over the last fifteen years a number of distinguished Oxford academic theologians have also engaged with the sciences in public and influential ways. Arthur Peacocke and John Brooke are both well-known because of their relationship with the Ian Ramsey Centre in the past and present ${ }^{10}$.

Three other scholars, whose works span over the last 15 years or so, also deserve to be mentioned. One such theologian to engage with these issues is Bishop Richard Harries, who like Samuel Wilberforce was Bishop of Oxford, in this case from 1987 to 2006. He became a member of the House of Lords as a Bishop in 1993 and was made a Life Peer on his retirement in 2006. Both in Oxford and in Parliament he has played a critical part in the public debate about the religious and ethical consequences of major scientific advances, particularly in human fertilisation, embryology and stem cell research. Ironically some years ago he joined forces with Richard Dawkins in taking a liberal stance opposing the Emmanuel School Foundation's teaching of creationism as part of their religious studies syllabus. This then led to his being interviewed for the Richard Dawkins Foundation for Reason and Science: one of these interviews in particular (2007) is to be found on You Tube and is particularly interesting for a more eirenical approach to these debates about Religion and Science (Richard Dawkins and Richard Harries Christianity 2008).

A fourth contributor to this debate is Emeritus Professor Keith Ward, who was the Regius Professor of Divinity, the most senior post in the Oxford Theology Faculty, from 1991 to 2004. In this capacity, and even more so since his

9.Originally taken from an observation by a science correspondent from The Observer [Easter 1992]) as a result of a public debate between Richard Dawkins and the then Archbishop of York, Dr John Habgood, himself an author of works on science and religion and a member and once President of The Science and Religion Forum. In this debate Dawkins charged the Archbishop for his views that he saw 'no contest' between science and religion.

10.Arthur Peacocke (1924-2006) began his career as a biochemist and later trained as a theologian and Anglican priest. One of the seminal works he edited is The Sciences and Theology in the Twentieth Century, University of Notre Dame Press, Indiana, 1981. He was the director of the lan Ramsey Centre in 1988 and 1995Indiana, 1981. He was the director of the lan Ramsey Centre in 1988 and 1995-
2006. 2006. 
retirement, his diverse interests have included entering the debates between religion and science. He has written lengthy publications on this issue ${ }^{11}$. One of his earliest works on this issue, God, chance and necessity (1996a), is a particular critique on some of the more personal and philosophical assumptions made by Dawkins, taking him to task for his hatred of religion as much as his defence of science, and advocating what has been termed as 'theistic metaphysics' as opposed to the theory of Dawkins (and of his Oxford colleague, Peter Atkins) known as 'material metaphysics' (Ward 1996b). Keith Ward is by training a philosophical theologian, and although some would argue his views are overly liberal, his defence of traditional theism is both gracious and trenchant. Another very recent example of this sort of engagement was a brief entry in The Church Times (Ward 2010), when he gave an interesting critique of Stephen Hawking, the physicist and cosmologist who was Lucasian Professor of Mathematics at the University of Cambridge until 2009, author of many books of which his A brief history of time (1995) stayed in several bestsellers' lists for almost five years. Ward's arresting title in The Church Times read 'Hawking is not far from God' (Ward 2010). In it he argued that Stephen Hawking's thesis, as developed in his new book, The grand design (2010), that physics has no need of God, is actually closer to theology than he, Hawking, might have realised. Ward argues this on the basis that, far from the laws of nature existing apart from the actual universe ('a very problematic hypothesis') (University of Oxford 2008) they pre-exist in the mind of God (which he admits is 'also problematic' [University of Oxford 2008]): but because both the theistic and the scientific materialist 'suppose that this universe originates from a supra-temporal realm that is intelligible and conceptually beautiful' (University of Oxford 2008) the two hypotheses are closer than one might think. 'Physics does not need God, but God explains very well why physics works' (University of Oxford 2008).

A fifth theologian is Alister McGrath, who is now Professor of Theology, Ministry and Education, and Head of the Centre for Theology, Religion and Culture at King's College, London. Prior to this he was a professor in Historical Theology in the Theology Faculty at Oxford University (McGrath \& Collicut McGrath 2007). A chemist and a molecular biophysicist by research and training, he gained his doctorate in 1977 to be followed by a first class degree in theology in 1978 and an honorary Doctor of Divinity in 2001 ${ }^{12}$. After ordination and a career including teaching and writing, mainly in theology, in both Oxford and Canada, he served as a Principal of Wycliffe Hall from 1995 to 2004. He has been undertaking a long-term research project in natural theology, funded by the John Templeton Foundation, since 2008, and one of his projects is a study of the 'iconic role' of Charles Darwin in 'atheistic apologetics'. He presented the Gifford Lectures at the University of Aberdeen in 2009, which have since been

11.One of his first publications was Religion and Creation in 1996. Since his retirement seminal works include The big questions in science and religion (2008), which examined 10 critical questions in the relationship between religion and science.

12.As his website indicates, the three-volume work Scientific Theology (2001-2003) shows how in the last two decades he has sought to bring these two disciplines together. published as A fine tuned universe. The quest for God in science and theology (2009). His Hulsean Lectures at the University of Cambridge (2010) will be published in 2011 as Darwinism and the Divine. Evolutionary thought and natural theology. From his many publications at least two concerns relevant to this discussion are discernible. The first is his work on the mutual relationship between the natural sciences and Christian theology, and the second, his interaction with what has been termed 'scientific atheism', again, best exemplified by Richard Dawkins (Richard Dawkins and Allister McGrath $2008)^{13}$. The much publicised interview, now on You Tube (The God Delusion and Alister E. McGrath 2007), between McGrath and Dawkins in 2006 showed the contours of their disagreements: for Dawkins, religion is 'intellectually impoverishing' because it 'cuts off investigation by providing easy, facile answers to deep and troubling questions, like the questions science tackles'. For McGrath:

... there are levels of explanation. There may well be a scientific level of explanation, which may be helpful insofar as it goes, but then we may want to add other things onto it which are not necessarily, in themselves, scientific but nonetheless significant in themselves ... I think they are things that can exist side by side, both being present, but operating on different levels ....

(Richard Dawkins and Allister McGrath - Christianity 2008)

In January and February 2009 the theology and science discourse, not only in Oxford, reached new heights (or depths) with a double advertising campaign. Ironically it was the Christian response, which received the most complaints, because of its politicising appeal (see Figure 4).

\section{The debates continue: A broader view of theology and of the sciences}

Thus far we have assumed that the debate centres on Christian theology and natural science. But - again keeping the Oxford provenance mainly in view - a good deal of research is taking place in Islamic theology as well. Dr Afifi Al-Akiti, who is a university lecturer in Islamic Studies and a senior research fellow at Worcester College, is a prolific writer, with a first degree in Scholastic Philosophy and the History of Science. He also holds an Oxford doctorate on Islam's greatest theologian, al-Ghazali (d. 1111). Most of Dr Al-Akiti's publications are on Islamic theology, philosophy and science, especially on discussions between Moslems and Christians in the Medievial period (University of Oxford 2011). The Oxford Centre for Islamic Studies, where he is also a Fellow, frequently offers seminars and conference papers on Islam and Science: for example, from April to June 2009 there was a special series on this issue, and the Centre's Journal of Islamic Studies often publishes articles on the relationship between religion, science and ethical questions relating to scientific research. The Centre has recently collaborated with Oxford University's Museum of the History of Science, in an exhibition 'Science and Arts in the Islamic World', 'Al Mizan' ('Balance') which looks especially at the relationship between 'scientific enquiry and artistic beauty' (Al-Mizan 2010).

13.Alister McGrath published with his wife Joanna Collicutt McGrath The Dawkins Delusion? Atheist Fundamentalism and the Denial of the Divine in 2007, as a direct
reference to Dawkins' book entitled The God Delusion (2006). The latter sparked off huge publicity in various live interviews and documentaries. 

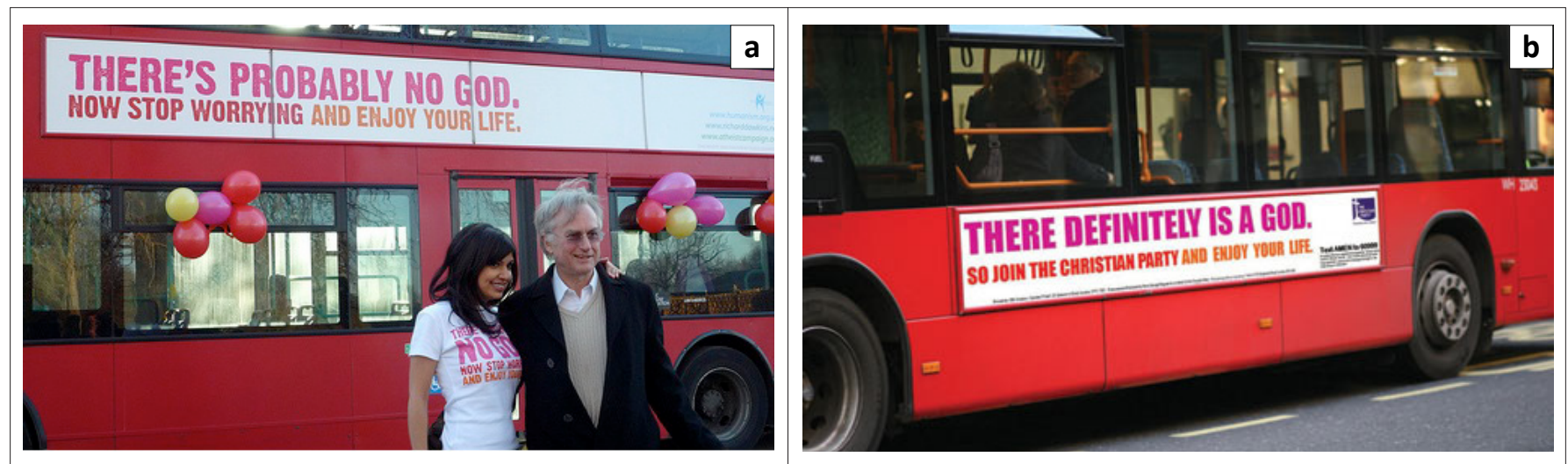

Source: a, Unknown; b, http://www.atheistbus.org.uk/

FIGURE 4: Professor Richard Dawkins at the launch of the (a) Atheist Bus Campaign in January 2009. The Christian Party launched their own advertisments (b) as a counter-response.

This paper has focussed on the relationship between theology and the natural sciences mainly at the University of Oxford. It is impossible at this stage to offer much about theology and the social sciences; but interestingly this is where teaching in my own subject, Old Testament Studies, has become dependent upon some of the disciplines normally associated with the social. For example, in teaching biblical archaeology, the dialogue between text and artefact requires some understanding of scientific techniques in archaeology (e.g. in the dating of pottery and inscriptions, and the measuring of environmental and demographic changes); teaching about the origins and nature of Israel and her religion, or about the Jews under Persian rule after the exile, requires a similar appreciation of anthropological and social scientific studies as they are applied to ancient peoples. At this very practical level the relationship between theology and the social sciences is overall positive and enriching, and although it often provides (usually welcomes) challenges to biblical studies, there are fewer public controversies and areas of distrust than in the relationship between theology and the physical sciences.

\section{Conclusion}

\section{A personal observation}

My own research is usually far removed from the world of scientific enquiry, for my work on biblical poetry (especially the Psalms) requires more literary, linguistic and conceptual skills. But I would argue that even here there are lessons to be learnt. The relationship between the text as something familiar and yet totally other provides an interesting model for our understanding of the immanence and transcendence of God, who is near enough for us to understand in part and distant enough to prevent us ever being able to exercise control in our partial knowledge of him. As my colleague John Barton (1996) writes:

Intellectual rigour in theology is likewise a matter of making alien truth part of one's own mind, being willing to accept divine transcendence without attempting to force God into our own image, and to embrace divine immanence without resisting the all-too-close presence of God. In our analogy, we read God; but God also reads us.

(Barton 1996:57)
Barton argues that this willingness to accept alien truth, a whole-hearted commitment without surrendering our critical faculty and a combination of intellectual and emotional modes of perception, are hallmarks not only of studying theology but also of almost any academic discipline; both in humanities and in the sciences. In this sense, it is not just that theology is more like the sciences than its opponents might often argue; the sciences are actually more like theology than is often assumed (Ward 2010) ${ }^{14}$. Too often we apologise for the significance of theology within the academy. But theologians and scientists together are engaged in making sense of our existence: so to recognise that the methods we use in theology can be exemplary in this engagement is an important way forward in establishing more collaboration with the sciences. I end these observations with a different take on the relationship between the two disciplines: far from theology having to become like another science, the sciences might be challenged to become more like theology.

\section{Acknowledgements Competing interests}

The author declares that she has no financial or personal relationship(s) which may have in appropriately influenced her in writing this paper.

\section{Note}

I am Reader in Old Testament at the University of Oxford, and I am the Fellow and Tutor in Theology at Worcester College, one of the 38 colleges within the University. My associations with the University of Pretoria have been through my specialist research interest in the Psalms and I have just returned from a most stimulating ProPsalms Conference hosted there by Dirk Human. I am primarily interested in the Psalms, in Hebrew poetry, in the religions of the ancient Near East and in the reception history of psalmody, both through Jewish and Christian traditions. I am not a scientist: so I do not intend to advance any one particular argument. Rather, I seek to offer an account of the nature of the historical and contemporary debates as they have affected theology at the University of Oxford, because they impact upon the way we

14.These observations have much in common with the writings of Keith Ward, referred to earlier, particularly in relation to his article 'Hawking is not far from God'. 
think and teach. I hope that readers will find resonances with the concerns expressed in their own academic settings. My conclusion seeks to draw some of these strands together and place them in a wider context, but what preceeds it is based upon my own non-specialist observations. It is a personal view of theology and the sciences at Oxford.

\section{References}

Al-Mizan, 2010, Sciences and Arts in the Islamic World, viewed 21 October 2011, from http://www.mhs.ox.ac.uk/almizan/

Barret, J., 2004, Why would anyone believe in God?, Cognitive Science of Religion Series, AltaMira Press, Walnut Creek, CA.

Barton, J., 1996, 'Theology and Other Sciences' Theology XCIX No. pp. 52-58. http:// dx.doi.org/10.1177/0040571X9509900109

Brooke, J.H., 1991, Science and religion: Some historical perspectives, CUP, Cambridge.

Cobb, J.B. \& Griffin, D.R., 1976, Process theology: An introductory exposition, Westminster Press, Philadelphia PA.

Darwin, C., 1895, On the origin of species by means of natural selection, John Murray, London, UK.

Dawkins, R., 1989, The selfish gene, revised edn., OUP, Oxford, UK.

Dawkins, R., 1994, 'The "know-nothings", the "know-alls", and the "no-contests", A lecture by Richard Dawkins extracted from The Nullifidian, December 1994, in Third World Traveler, viewed 21 October 2011, from http://www. thirdworldtraveler.com/Dawkins_Richard/NoNothings_Dawkins.html

Dawkins, R., 2006, The God delusion, Bantam Press, London, UK.

Dixon, T., 2008, Science and religion: A very short introduction, OUP, Oxford, UK.

Gillingham, S.E., 2009, Encountering Burges: Reflections on the art and architecture of the chapel at Worcester College, Oxford, Third Millennium Publishing, London, UK.

Hawking, S., 1995, A brief history in time, Bantam Press/Random House, London, UK. Hawking, S. \& Mlodinow, L., 2010, The grand design, Bantom Press, London, UK. Heilbron, J.H., 2010, Galileo, OUP, Oxford, UK.
Ian Ramsey Centre n.d., Ian Ramsey Centre, viewed 21 October 2011, from http:// www.ianramseycentre.org/

McGrath, A., 2009, A fine tuned universe. The quest for God in science and theology (Gifford Lectures), Westminster John Knox Press, Louisville, KY.

McGrath, A. \& Collicutt McGrath, J., 2007, The Dawkins delusion? Atheist fundamentalism and the denial of the divine, SPCK, London, UK, viewed 21 October 2011, from http://users.ox.ac.uk/ mcgrath/

Peacocke, A., 1981, The sciences and theology in the twentieth century, University of Notre Dame Press, Indiana.

Polkinghorne, J., 2005, Exploring reality: The intertwining of science and religion, Yale University Press, Yale.

Richard Dawkins and Allister McGrath - Christianity, 2008, interview, viewed 21 October 2011, from http://www.youtube.com/watch?v=20Tc6EQ94GE

Richard Dawkins and Richard Harries - Christianity, 2008, interview, viewed 21 October 2011, from http://www.youtube.com/watch?v=Hpb59q55_Bs

Trigg, R., 2007, Religion in public life: Must faith be privatised?, OUP, Oxford, UK.

The God Delusion and Alister E. McGrath, 2007, audio recording, viewed 21 Octobe 2011, from http://richarddawkins.net/audio/1795-the-god-delusion-and-alistere-mcgrath

Ukraine.com, 2001, Richard Dawkins vs Dr John Habgood, viewed 21 October 2011 from http://www.ukraine.com/forums/religion/1756-richard-dawkins-vs-dr-john -habgood.html

University of Oxford, 2011, 'Dr Afifi al-Akiti', Faculty of Theology, viewed 21 October 2011, from http://www.theology.ox.ac.uk/people/staff-list/dr-afifi-al-akiti.html

University of Oxford, 2008, Major new Oxford study of the nature and origins of religious belief, viewed, 21 October 2011, from http://www.ox.ac.uk/media/ news_releases_for_journalists $/ 080222$.html

Vallely, P., 2008, 'Into a fifth phase of science and faith', The Church Times, 26 September 2008, p.13.

Van Wolde, E., 1996, Stories of the beginning: Genesis 1-11 and other creation stories, Morehouse Publishing Company, Seabury Books, Harrisburg, PA.

Ward, K., 1996a, God, chance and necessity, Oneworld Publications, Oxford, UK.

Ward, K., 1996b, Religion and creation, Clarendon Press, Oxford, UK. http://dx.doi. org/10.1093/acprof:oso/9780198263937.001.0001

Ward, K., 2008, The big questions in science and religion, Templeton Foundation Press, West Conshohocken, PA.

Ward, K., 2010, 'Hawking is not far from God', Church Times, Issue 7695, September, viewed 21 October 2011, from http://www.churchtimes.co.uk/content.asp? id $=100242$ 